\title{
Bacteriocinogenic Bacillus spp. Isolated from Korean Fermented Cabbage (Kimchi)_Beneficial or Hazardous?
}

\author{
Joanna Ivy Irorita Fugaban (D), Jorge Enrique Vazquez Bucheli $\mathbb{D}$, Wilhelm Heinrich Holzapfel (D) \\ and Svetoslav Dimitrov Todorov *(D) \\ ProBacLab, Department of Advanced Convergence, Handong Global University, Pohang, \\ Gyeongbuk 37554, Korea; jifugaban@up.edu.ph (J.I.I.F.); jorge_jbv@hotmail.com (J.E.V.B.); \\ wilhelm@woodapple.net (W.H.H.) \\ * Correspondence: slavi310570@abv.bg; Tel.: +82-10-3490-3152
}

check for

updates

Citation: Irorita Fugaban,

J.I.; Vazquez Bucheli, J.E.;

Holzapfel, W.H.; Todorov, S.D.

Bacteriocinogenic Bacillus spp.

Isolated from Korean Fermented

Cabbage (Kimchi)—Beneficial or

Hazardous? Fermentation 2021, 7, 56.

https://doi.org/10.3390/

fermentation7020056

Academic Editor: Hiroshi Kitagaki

Received: 19 March 2021

Accepted: 4 April 2021

Published: 7 April 2021

Publisher's Note: MDPI stays neutral with regard to jurisdictional claims in published maps and institutional affiliations.

Copyright: (C) 2021 by the authors. Licensee MDPI, Basel, Switzerland. This article is an open access article distributed under the terms and conditions of the Creative Commons Attribution (CC BY) license (https:/ / creativecommons.org/licenses/by/ $4.0 /)$.

\begin{abstract}
Bacillus velezensis ST03 and ST32, Bacillus amyloliquefaciens ST06 and ST109, and Bacillus subtilis ST08 were isolated from artisanal-produced kimchi and were identified based on 16S rRNA partial sequencing. DNA obtained from the investigated bacilli generated positive results for lichenicidin, iturin, subtilosin, and surfactin on a strain-specific basis. The strains were found to produce antimicrobial metabolites with activity levels ranging between 800 and $1600 \mathrm{AU} / \mathrm{mL}$ on a strainspecific basis, as determined against Listeria monocytogenes ATCC15313. Moreover, all tested strains in this study were still active after treatment with proteolytic enzymes, even with reduced inhibition zones compared to the controls, pointing to additional antimicrobial activity possibly related to a non-proteinaceous molecular structure. Most probably these strains may express surfactin as an additional factor in their complex antimicrobial activity. B. amyloliquefaciens ST09 and B. velezensis ST03 and ST32 were characterized as positive for $\beta$-hemolysis. B. subtilis ST08 was shown to be positive for $h b l C$ and $n h e C$ and B. amyloliquefaciens ST109 for nheB. B. amyloliquefaciens ST109 generated positive results for gelatinase activity. The ability of the studied Bacillus strains to metabolize different carbohydrate sources was done based on the API50CHB test, while the enzyme production profile was recorded by the APIZym kit. All studied strains were positive producers for biogenic amines production. Studied Bacillus spp. strains were resistant to some of the evaluated antibiotics, tested according to recommendations of CLSI and EFSA.
\end{abstract}

Keywords: Bacillus velezensis; Bacillus amyloliquefaciens; Bacillus subtilis; Listeria monocytogenes; bacteriocins; safety; antibiotic resistance

\section{Introduction}

Evaluation of microbial diversity in different traditional fermented food products may open ways for isolating beneficial microbial strains. Probiotic cultures, bacteriocinogenic strains, producers of enzymes, exopolysaccharides, and other bioactive metabolites were obtained from fermented food products of all continents and were explored by biotechnical, pharmaceutical, and food industries [1,2]. Asian countries are considered as a promising source of different beneficial microbial strains. This huge potential is suggested by several remote regions on this continent and the fact that local groups have been producing typical fermented food products according to conventional artisanal practices and without commercial standardized starter cultures [3]. Moreover, the extent of biological diversity can be considered as an indicator for the health of the planet.

Kimchi is perhaps the most well-known among several traditional fermented Korean food products, and it forms part of the heritage of Asian culture, especially of the Korean peninsula. According to Encyclopedia Britannica there are hundreds of varieties of kimchi based on the methods of preparation and the specific raw materials used including vegetables such as cabbage, Korean radish, leak; and supplemented with a varying selection of seasonings including salts, chili powder, spring onions, garlic, fermented seafood (jeotkal), 
and ginger $[4,5]$. However, due to lack of standardization, preparation of traditional fermented food products can be hiding unexpected problems related to their safety and quality. In general, good manufacturing practices are an assurance for the safety of the products. Food fermentation processes were developed and established over centuries. Fermentation processes of food preparation normally involve participation of microorganisms that can produce different arsenals of antimicrobial metabolites, including organic acids, hydrogen peroxide, carbon dioxide, antibiotics, antimicrobial proteins, bioactive peptides, and low molecular antimicrobial organic molecules [6,7]. Changes in water activity, redox potential, and $\mathrm{pH}$ are some of the key factors involved in food safety [8] and stability, and can change in a positive way during fermentation of kimchi. Food fermentation can be considered as a dynamic process in which implicit factors related to microbial interactions (competition, symbiosis, and synergism) play a key role. However, food safety assurance not only implies the absence of pathogenic or food spoilage microorganisms, but also of toxic or detrimental metabolites or residues. Some microbial cultures can be producers of biogenic amines by amino acid decarboxylase activity [9]. Potentially pathogenic strains can be characterized by either hemolytic [10] and/or gelatinase or mucus degrading activities [11]. These characteristics can serve as indicator(s) of the potential virulence of a specific strain. Some virulent characteristics of bacterial cultures maybe expressed only under specific conditions, e.g., at a typical body temperature of $37^{\circ} \mathrm{C}$, and even escape detection during fermentation processes normally occurring at room temperature [12].

Representative strains of Bacillus spp. are found to be biotechnological application as producers of a variety of bioactive metabolites, including antimicrobial proteins, antibiotics, enzymes, exopolysaccharides, vitamins, and surfactants [13-17]. Industrial exploring of particular Bacillus strains is widely practiced $[18,19]$ and has been part of the preparation of different fermented food products including kimchi [20]. Even when the beneficial potential of different Bacillus strains has been widely proven, some representatives of this genus have also been clearly identified as human and animal pathogens, including Bacillus anthracis [21] and opportunistic pathogens such as some strains of Bacillus cereus [22]. On the beneficial side, different strains of the species B. clausii, B. coagulans, B. licheniformis, B. polyfermenticus, B. pumilus, and B. subtilis have been widely commercialized as probiotics and their efficacy proven [23-25]. In Italy, a B. clausii spore suspension has been available since 1958 as part of endospore-based probiotics for human consumption [26].

In our study, we attempted to isolate producers lactic acid bacteria (LAB) and Bacillus spp.) of antimicrobial metabolites from kimchi of locally produced fermented cabbage (Pohang region, Republic of Korea). However, based on the predominate yield of Bacillus spp. isolated in preliminary screening, the present work was focused on obtained bacilli. In addition to the antibacterial properties of the expressed antimicrobial(s) and their specific potential application in the control of food borne pathogen organisms, represented by Listeria monocytogenes, a well-known, highly contagious pathogen able to survive at low $\mathrm{pH}$ and refrigeration temperatures, an additional goal has been to collect more information about the safety of kimchi.

\section{Materials and Methods}

\subsection{Isolation of Antagonistic Strains and Evaluation of Antimicrobial Activity}

Kimchi, a traditional Korean fermented cabbage, was evaluated as a source for isolation of bacteriocinogenic strains. Kimchi samples were obtained from artisanal sources prepared by local producers (Pohang, Republic of Korea). Each sample of around $50 \mathrm{~g}$ was collected aseptically and according to good microbiological practices, and investigated for the presence of bacterial strains with the potential ability to produce antimicrobial metabolites. Twenty-five grams of each kimchi sample were homogenized with 9 volumes of sterile saline solution $(0.85 \% \mathrm{NaCl}, m / v)$ in sterile sample bags (Whirl-Pak stomacher sampling bag, Neogen, Lansing, MI, USA) and homogenized in a stomacher (Stomacher 400 Circulator, Worthing, West Sussex, UK) for 3-5 min. After 10x serial dilution, $100 \mu \mathrm{L}$ were surfaceplated in triplicates on de Man, Rogosa and Sharpe (MRS) (Difco, Detroit, MI, USA) 
supplemented with $2 \%$ agar (Difco). An extra layer of $2 \%$ agar was added to each plate and then incubated for $48 \mathrm{~h}$ at $37^{\circ} \mathrm{C}$. Plates were covered with an additional layer of Brain Heart Infusion (BHI) (Difco) supplemented with 1\% agar and L. monocytogenes ATCC15313 at a final concentration of around $10^{5} \mathrm{CFU} / \mathrm{mL}$ and incubated for an additional $24 \mathrm{~h}$ at 37 ${ }^{\circ} \mathrm{C}$. Colonies surrounded by inhibition zones larger than $5 \mathrm{~mm}$ in diameter were selected, isolated, and cultured in MRS broth for $24 \mathrm{~h}$ at $37^{\circ} \mathrm{C}$. Bacterial cultures were evaluated based on recommendations for good microbiological practices for purity, macroscopic observation of colonies, microscopic observation, and Gram-staining. The production of oxidase and catalase enzymes was determined in addition to tests recommended by Bergey's Manual of Systematic Bacteriology of Archaea and Bacteria [27]. All pure bacterial cultures were stored at $-80{ }^{\circ} \mathrm{C}$ in presence of $20 \%$ glycerol. All additional bacterial cultures applied in this study and microorganisms part of the spectrum of activity evaluation experiments (Table 1) were grown under their respective recommended growth conditions (media and temperatures) and stored at $-80{ }^{\circ} \mathrm{C}$ in the presence of $20 \%$ glycerol as the cryoprotector. Before each experiment, all cultures were propagated at least 2 times.

Table 1. Spectrum of activity of supernatants from B. velezensis ST03, B. amyloliquefaciens ST06, B. subtilis ST08, B. velezensis ST32, and B. amyloliquefaciens ST109 against selected bacteria from different culture collections.

\begin{tabular}{|c|c|c|c|c|c|c|c|c|c|c|}
\hline & \multicolumn{10}{|c|}{ Activity of Bacteriocins Produced by } \\
\hline & & ST03 & & ST06 & & ST08 & & ST32 & & ST109 \\
\hline Bacillus spp. & $0 / 12$ * & & $2 / 12$ & & $1 / 12$ & & $1 / 12$ & & $2 / 12$ & \\
\hline Bacillus amyloliquefaciens & & $0 / 2$ & & $0 / 2$ & & $0 / 2$ & & $0 / 2$ & & $0 / 2$ \\
\hline Bacillus velezensis & & $0 / 1$ & & $0 / 1$ & & $0 / 1$ & & $0 / 1$ & & $0 / 1$ \\
\hline Bacillus subtilis & & $0 / 4$ & & $2 / 4$ & & $1 / 4$ & & $0 / 4$ & & $2 / 4$ \\
\hline Bacillus cereus & & $0 / 1$ & & $0 / 1$ & & $0 / 1$ & & $0 / 1$ & & $0 / 1$ \\
\hline Bacillus pumilus & & $0 / 1$ & & $0 / 1$ & & $0 / 1$ & & $0 / 1$ & & $0 / 1$ \\
\hline Bacillus sonorensis & & $0 / 1$ & & $0 / 1$ & & $0 / 1$ & & $0 / 1$ & & $0 / 1$ \\
\hline Bacillus megaterium & & $0 / 1$ & & $0 / 1$ & & $0 / 1$ & & $0 / 1$ & & $0 / 1$ \\
\hline Bacillus firmus & & $0 / 1$ & & $0 / 1$ & & $0 / 1$ & & $1 / 1$ & & $0 / 1$ \\
\hline Enterococcus spp. & $0 / 51$ & & $1 / 51$ & & $8 / 51$ & & $3 / 51$ & & $5 / 51$ & \\
\hline Enterococcus faecium & & $0 / 12$ & & $1 / 12$ & & $2 / 12$ & & $1 / 12$ & & $1 / 12$ \\
\hline Enterococcus avium & & $0 / 3$ & & $0 / 3$ & & $0 / 3$ & & $0 / 3$ & & $1 / 3$ \\
\hline Enterococcus faecalis & & $0 / 2$ & & $0 / 2$ & & $0 / 2$ & & $0 / 2$ & & $0 / 2$ \\
\hline Enterococcus thailandicus & & $0 / 1$ & & $0 / 1$ & & $1 / 1$ & & $0 / 1$ & & $0 / 1$ \\
\hline Enterococcus durans & & $0 / 1$ & & $0 / 1$ & & $0 / 1$ & & $0 / 1$ & & $0 / 1$ \\
\hline Enterococcus gallinarum & & $0 / 1$ & & $0 / 1$ & & $1 / 1$ & & $1 / 1$ & & $0 / 1$ \\
\hline VRE (vancomycin resistant enterococci) & & $0 / 31$ & & $0 / 31$ & & $4 / 31$ & & $1 / 31$ & & $3 / 31$ \\
\hline Lactobacillus spp. & $0 / 50$ & & $0 / 50$ & & $0 / 50$ & & $6 / 50$ & & $0 / 50$ & \\
\hline Lactobacillus coryniformis & & $0 / 1$ & & $0 / 1$ & & $0 / 1$ & & $0 / 1$ & & $0 / 1$ \\
\hline Lactobacillus plantarum & & $0 / 9$ & & $0 / 9$ & & $0 / 9$ & & $0 / 9$ & & $0 / 9$ \\
\hline Lactobacillus brevis & & $0 / 3$ & & $0 / 3$ & & $0 / 3$ & & $2 / 3$ & & $0 / 3$ \\
\hline Lactobacillus curvatus & & $0 / 2$ & & $0 / 2$ & & $0 / 2$ & & $2 / 2$ & & $0 / 2$ \\
\hline Lactobacillus fermentum & & $0 / 3$ & & $0 / 3$ & & $0 / 3$ & & $0 / 3$ & & $0 / 3$ \\
\hline Lactobacillus paracasei & & $0 / 5$ & & $0 / 5$ & & $0 / 5$ & & $1 / 5$ & & $0 / 5$ \\
\hline Lactobacillus plantarum & & $0 / 9$ & & $0 / 9$ & & $0 / 9$ & & $1 / 9$ & & $0 / 9$ \\
\hline Lactobacillus reuteri & & $0 / 2$ & & $0 / 2$ & & $0 / 2$ & & $0 / 2$ & & $0 / 2$ \\
\hline Lactobacillus rhamnosus & & $0 / 5$ & & $0 / 5$ & & $0 / 5$ & & $0 / 5$ & & $0 / 5$ \\
\hline Lactobacillus sakei & & $0 / 4$ & & $0 / 4$ & & $0 / 4$ & & $0 / 4$ & & $0 / 4$ \\
\hline Lactobacillus salivarius & & $0 / 3$ & & $0 / 3$ & & $0 / 3$ & & $0 / 3$ & & $0 / 3$ \\
\hline Lactobacillus sanikiri & & $0 / 4$ & & $0 / 4$ & & $0 / 4$ & & $0 / 4$ & & $0 / 4$ \\
\hline Lactococcus spp. & $0 / 2$ & & $0 / 2$ & & $0 / 2$ & & $0 / 2$ & & $0 / 2$ & \\
\hline Lactococcus lactis & & $0 / 2$ & & $0 / 2$ & & $0 / 2$ & & $0 / 2$ & & $0 / 2$ \\
\hline Leuconostoc spp. & $0 / 8$ & & $0 / 8$ & & $0 / 8$ & & $2 / 8$ & & $0 / 8$ & \\
\hline Leuconostoc citreum & & $0 / 1$ & & $0 / 1$ & & $0 / 1$ & & $0 / 1$ & & $0 / 1$ \\
\hline Leuconostoc mesenteroides & & $0 / 7$ & & $0 / 7$ & & $0 / 7$ & & $2 / 7$ & & $0 / 7$ \\
\hline Listeria spp. & $5 / 5$ & & $5 / 5$ & & $5 / 5$ & & $5 / 5$ & & $5 / 5$ & \\
\hline Listeria iпnосиа & & $2 / 2$ & & $2 / 2$ & & $2 / 2$ & & $2 / 2$ & & $2 / 2$ \\
\hline Listeria monocytogenes & & $3 / 3$ & & $3 / 3$ & & $3 / 3$ & & $3 / 3$ & & $3 / 3$ \\
\hline
\end{tabular}


Table 1. Cont.

\begin{tabular}{|c|c|c|c|c|c|c|c|c|c|}
\hline & & \multicolumn{8}{|c|}{ Activity of Bacteriocins Produced by } \\
\hline & & & ST03 & & ST06 & ST08 & & ST32 & ST109 \\
\hline \multirow{4}{*}{ Pediococcus spp. } & & $0 / 9$ & & $0 / 9$ & $2 / 9$ & & $0 / 9$ & & \\
\hline & Pediococcus acidilactici & & $0 / 3$ & & $0 / 3$ & $0 / 3$ & & $0 / 3$ & $0 / 3$ \\
\hline & Pediococcus lolii & & $0 / 1$ & & $0 / 1$ & $0 / 1$ & & $0 / 1$ & $0 / 1$ \\
\hline & Pediococcus pentosaceus & & $0 / 5$ & & $0 / 5$ & $2 / 5$ & & $0 / 5$ & $0 / 5$ \\
\hline \multirow[t]{2}{*}{ Weissella spp. } & & $0 / 1$ & & $0 / 1$ & $0 / 1$ & & $0 / 1$ & & \\
\hline & Weissella cibaria & & $0 / 1$ & & $0 / 1$ & $0 / 1$ & & $0 / 1$ & $0 / 1$ \\
\hline Total tested strains & & $5 / 138$ & & $11 / 138$ & $16 / 138$ & & $16 / 138$ & & \\
\hline
\end{tabular}

* The number of strains sensitive to the tested antimicrobial(s) is shown against the total number of tested strains. Data on each genus are summarized in bold; representatives (species) are shown below each genus.

\subsection{Differentiation and Identification of Selected Isolates}

Bacterial isolates of interest with confirmed production of antimicrobial metabolites, were subjected to DNA fingerprinting through Random Amplification of Polymorphic DNA (RAPD)-PCR and subsequently identified on basis of tests recommended by Bergey's manual [27] and by $16 \mathrm{~S}$ rRNA sequencing. Bacterial cultures were grown in $50 \mathrm{~mL}$ of MRS broth for $24 \mathrm{~h}$ at $37^{\circ} \mathrm{C}$, and for future isolation of DNA, cells were collected by centrifugation $\left(8000 \times g, 10 \mathrm{~min}, 4^{\circ} \mathrm{C}\right)$. Total DNA was obtained using the ZR Fungal/Bacterial DNA kit (Zymo Research, Irvine, CA, USA) in accordance with the manufacturer's protocol and quantified by SPECTROstar Nano nanodrop (BMG LABTECH, Ortenberg, Germany). Differentiation between the evaluated cultures was based on RAPD-PCR performed with primers OPL-01 (5'-GGC ATG ACC T-3'), OPL-09 (5'-TGC GAG AGT C-3'), and OPL-11 (5'-ACG ATG AGC C-3') according to de Moraes et al. [28] on a Veriti 96 well Thermal Cycler, Applied Biosystems (Thermo Scientific, Waltham, MA, USA). Specificity of the obtained amplicons was evaluated via gel electrophoresis on $1.0 \%(w / v)$ agarose gels for $1 \mathrm{~h}$ in the presence of $0.02 \mu \mathrm{L} / \mathrm{mL}$ of SYBR ${ }^{\circledR}$ Safe (Thermo Fisher) in 1x TAE buffer at 100 V (GH-200 Genera Biosystems, Victoria, Australia; Elite 300 Plus Power Supply, Wealtec Bioscience Co., Ltd., Taiwan) and visualized using Omega Lum ${ }^{\mathrm{TM}} \mathrm{G}$ gel documenter (Aplegen, Inc., Pleasanton, CA, USA). The RAPD profiles generated from the isolates were analyzed and specific profiles and their representative strains were selected, and subjected to identification based on 16S rRNA [28] on Veriti 96 well Thermal Cycler, Applied Biosystems, and further sequenced at the SolGent Analysis Services (Solgent Co. Ltd., Daejeon, Republic of Korea). The generated sequences were analyzed using the Basic Local Alignment Search Tool (BLAST, GenBank, National Center for Biotechnology Information, Bethesda, MD, USA) for identification.

\subsection{Sugar Fermentation Profile (API50CHB) and Production of Enzymes (APIZym)}

Sugar fermentation abilities of the evaluated strains were studied by culturing in API50CHB strips in accordance with the manufacturer's recommendations (bioMérieux, Marcy l'Etoile, France) at $37^{\circ} \mathrm{C}$ for 24,48 , and $72 \mathrm{~h}$. In a separate experiment, the enzymatic activity profiles of studied strains, previously grown in MRS for $24 \mathrm{~h}$ at $37{ }^{\circ} \mathrm{C}$ were determined using APIZYM strips (bioMérieux), in accordance with the manufacturer's instructions and incubated at $37^{\circ} \mathrm{C}$ for $4 \mathrm{~h}$. The evaluation of the enzymatic activity was based on changes in the intensity of coloration in accordance with the manufacturer's instructions (bioMérieux).

\subsection{Detection of Bacteriocin Genes and Other Antimicrobial Genes}

DNA from the selected strain, isolated as described before, was scanned for presence of different genes related to previously described antimicrobials, including Class IIa bacteriocins (Oli48/105: 5' - TAY GGI AAY GGI GTI TAY TG -3' and 5'-CYT CDA TNG CRT TRT C $-3^{\prime}$ ); lichenicidin (bli: $5^{\prime}$ - GGA AAT GAT TCT TTC ATG G $-3^{\prime}$ and $5^{\prime}-$ TTA GTT ACA GCT TGG CAT G-3'), thuricin (thu: 5'- GTA GGT CAA ATG GAA ACA C-3' and 5'- TTA ACT TGC AGT ACT AGC TC-3'), iturin (ituc: $5^{\prime}$ - GGC TGC TGC AGA TGC TTT AT-3' 
and $5^{\prime}$ - TCG CAG ATA ATC GCA GTG AG-3'), surfactin (srfa: 5' - TCG GGA CAG GAA GAC ATC AT- $3^{\prime}$ and $5^{\prime}$ - CCT CTC AAA CGG ATA ATC CTG A-3'), coagulin (coa: $5^{\prime}$ - GGT GGT AAA TAC TAC GGT AAT GGG GT-3' and $5^{\prime}$ - GTG TCT AAA TTA CTG GTT GAT TCG T-3'), subtilosin (sbo: $5^{\prime}$ - GGT TGT GCA ACA TGC TCG AT- $3^{\prime}$ and $5^{\prime}$ - CTC AGG AAG CTG GTG AAC TC-3'), and pediocin PA-1(ped: 5' - CAA GAT CGT TAA CCA GTT T- $3^{\prime}$ and $5^{\prime}$ - CCGTTG TTC CCA TAG TCT AA-3') $[29,30]$ on Veriti 96-well Thermal Cycler, Applied Biosystems. The generated amplicons were visualized on gel electrophoresis on $1.0-2.0 \%(w / v)$ agarose gels in $1 \times$ TAE buffer at $100 \mathrm{~V}$ for $1 \mathrm{~h}$ in the presence of $0.02 \mu \mathrm{L} / \mathrm{mL}$ of SYBR ${ }^{\circledR}$ Safe (Thermo Fisher) (GH-200 Genera Biosystems/Elite 300 Plus Power Supply) and visualized using OmegaLum ${ }^{\mathrm{TM}} \mathrm{G}$ gel documenter (Aplegen).

\subsection{Determination of Antimicrobial Activity and Nature of Antimicrobial Agent(s)}

The selected and previously identified producers of antimicrobial metabolites were grown in MRS at $37^{\circ} \mathrm{C}$ for $24 \mathrm{~h}$. The $\mathrm{pH}$ of the cell-free supernatant (CFS), obtained by centrifugation $\left(8000 \times g, 10 \mathrm{~min}, 20^{\circ} \mathrm{C}\right)$, was adjusted to $\mathrm{pH} 5.5-6.0$ with sterile $1 \mathrm{M}$ of $\mathrm{NaOH}$, subjected to $80^{\circ} \mathrm{C}$ for $10 \mathrm{~min}$, and filtered via $0.20-\mu \mathrm{m}$ syringe filters (Sartorius Ministart Syringe Filter, Göttingen, Germany). Antimicrobial properties of the obtained CFS were tested for activity against L. monocytogenes ATCC15313 formerly used in the initial screening process for selection of producers of antimicrobials and, in addition, against selected test strains from the culture collections of HEM Inc. (Holzapfel Effective Microbes Inc., Pohang, Republic of Korea), KCTC (Korean Culture Type Collection, Jeongeup, Republic of Korea), KACC (Korean Agricultural Culture Collection, Jeollabuk-do, Republic of Korea), and ATCC (American Type Culture Collection, Manassas, VA, USA), listed in Table 1 . These strains were incorporated in the recommended growth media supplemented with $1 \%$ agar at a final concentration of $10^{5} \mathrm{CFU} / \mathrm{mL}$, and $10 \mu \mathrm{L}$ of previously prepared CFS were deposited on the surface. Plates were kept for $1 \mathrm{~h}$ at room temperature in order to facilitate diffusion of the tested CFS and then incubated at temperatures recommended for the test microorganisms according to dos Santos et al. [31]. Diameters of the inhibition zones greater than $2 \mathrm{~mm}$ were considered as positive evidence for potential production of antimicrobial metabolites, including bacteriocins. For evaluating the nature of the inhibitory agent, possible inhibition due to organic acids and $\mathrm{H}_{2} \mathrm{O}_{2}$ was excluded based on the specificity of the pretreated CFS. All experiments were performed in triplicate on at least two independent occasions.

For evaluation of the titer of produced extracellular antimicrobial metabolites, the approach recommended by Todorov et al. [32] was applied. CFS obtained as described before was serially diluted two-fold in sterile $100-\mathrm{mM}$ phosphate buffer $\left(\mathrm{K}_{2} \mathrm{HPO}_{4} / \mathrm{KH}_{2} \mathrm{PO}_{4}\right)$ with a pH of 6.5 , and $10 \mu \mathrm{L}$ of each dilution were tested against L. monocytogenes ATCC15313 as previously described, with inhibition zones of at least $2 \mathrm{~mm}$ in diameter considered as positive. Levels of antimicrobial activity were expressed as arbitrary units per milliliter $(\mathrm{AU} / \mathrm{mL})$, taking into consideration a value corresponding to the reciprocal of the highest dilution that presented inhibitory halos from each experiment [32].

The proteinaceous nature of the produced extracellular antimicrobial compounds in the CFS was analyzed according to recommendations of dos Santos et al. [31]. CFS samples were subjected to treatment with different proteolytic enzymes (proteinase $\mathrm{K}$, pronase, pepsin, trypsin, and $\alpha$-chymotrypsin for confirmation of proteinaceous nature), $\alpha$-amylase (for evaluation of the potential presence of carbohydrate moieties, which are part of the active molecular complex), and catalase (for excluding possible $\mathrm{H}_{2} \mathrm{O}_{2}$ production) (all enzymes from Sigma-Aldrich, St. Louis, MO, USA) at a final concentration of $0.1 \mathrm{mg} / \mathrm{mL}$ at $37^{\circ} \mathrm{C}$ for $2 \mathrm{~h}$. To stop the enzymatic reactions, set-ups were heat treated $\left(95^{\circ} \mathrm{C}\right.$ for $\left.3 \mathrm{~min}\right)$ and then evaluated for evidence of active antimicrobial proteins, as described above [31]. Antimicrobial activity was determined against L. monocytogenes ATCC15313 as the test microorganism. In addition, CFS of the examined strain not treated with enzymes, and pure enzymes were evaluated as controls. 


\subsection{Stability of the Antimicrobial Substance(s)—pH, Temperature, and Chemicals}

Antimicrobial metabolites produced by the studied strain were evaluated for its activity in the presence of some chemicals, and at different temperatures and $\mathrm{pH}$ values [31]. Previously prepared CFS was mixed with $10 \mathrm{mg} / \mathrm{mL}$ of Tween 20 , Tween $80, \mathrm{NaCl}$, SDS, EDTA (all provided from Sigma-Aldrich), milk (Difco), and glycerol (Junsei Chemical Co., Ltd., Nihonbashi-honcho, Chuo-ku, Tokyo, Japan) to a final volume of $2 \mathrm{~mL}$ and incubated for 60 and $120 \mathrm{~min}$ at $37^{\circ} \mathrm{C}$. Before testing for antimicrobial activity, the $\mathrm{pH}$ of all experimental set-ups was adjusted to 5.5-6.5 if needed. In the experiment for evaluation of the effect of $\mathrm{pH}, \mathrm{CFS}$ of the selected strains was prepared as described previously, and adjusted to $\mathrm{pH}$ values of 2.0, 4.0, 6.0, 8.0, and 10.0, respectively (with $1 \mathrm{M}$ of $\mathrm{HCl}$ or $1 \mathrm{M}$ of $\mathrm{NaOH}$ ), and incubated for 60 and $120 \mathrm{~min}$ at $37^{\circ} \mathrm{C}$. Effect of temperature on antimicrobial metabolites stability was evaluated by incubating previously prepared CFS of the evaluated strain (with adjusted $\mathrm{pH} 5.5-6.5$ ) at $30,37,45,60,80$, and $100^{\circ} \mathrm{C}$, respectively, for 60 and $120 \mathrm{~min}$, and by autoclaving at $121^{\circ} \mathrm{C}$ for $20 \mathrm{~min}$. Activity of all set-ups were tested against $L$. monocytogenes ATCC15313, a sensitive indicator strain. Untreated CFSs of the examined strains at the examined temperatures, $\mathrm{pH}$, or chemicals and solutions of applied chemicals were evaluated as controls.

\subsection{Screening of Virulence Genes}

In these experiments, genes, parts of the expression of hemolysin BL, and nonhemolytic enterotoxin were evaluated by PCR reactions [33], performed on the Veriti 96-well Thermal Cycler, Applied Biosystems. The selected strains were tested for the presence of virulence genes encoding hemolysin BL (hblA: $5^{\prime}$ - AAG CAA TGG AAT ACA ATG GG -3' and 5' - AGA ATC TAA ATC ATG CCA CTG C - $3^{\prime}$; hblB: $5^{\prime}$ - AAG CAA TGG AAT ACA ATG GG $-3^{\prime}$ and $5^{\prime}$ - AAT ATG TCC CAG TAC ACC CG $-3^{\prime}$; hblC: $5^{\prime}$ - GAT ACY AAT GTG GCA ACT GC $-3^{\prime}$ and $5^{\prime}-$ TTG AGA CTG CTC GYT AGT TG $-3^{\prime}$ ) and nonhemolytic enterotoxin (nheA: $5^{\prime}$ - GTG AGG ATC ACA ATC ACC GC $-3^{\prime}$ and $5^{\prime}$ - ACG AAT GTA ATT TGA GTC GTC GC $-3^{\prime}$; nheB: $5^{\prime}$ - TTT AGT GGA TCT GTA CGC $-3^{\prime}$ and $5^{\prime}$ - TTA ATG TTC GTT AAT CCT GC $-3^{\prime}$; nhe C $5^{\prime}$ - TGG ATT CCA AGA TGT AAC G $-3^{\prime}$ and $5^{\prime}$ - ATT ACG ACT TCT GCT TGT GC $-3^{\prime}$ ), in accordance with the PCR protocols of Guinebretière et al. [33]. The generated amplicons were separated via gel electrophoresis on $1.0-2.0 \%(w / v)$ agarose gels in $1 \times$ TAE buffer at $100 \mathrm{~V}$ for $1 \mathrm{~h}$ in presence of $0.02 \mu \mathrm{L} / \mathrm{mL}$ of SYBR ${ }^{\circledR}$ Safe (Thermo Fisher) as described before.

\subsection{Virulence Activity-Physiological Approach}

The evaluated strains were investigated by selected phenotypic tests to identify their hemolytic activity and gelatinase production according to Colombo et al. [11]. All tests were performed in at least three independent replicates.

The representatives of the evaluated culture were streaked on the surface of trypticase soy agar (TSA) supplemented with $5 \%(v / v)$ defibrinated sheep blood (Synergy Innovation, Seongnam-si, Republic of Korea). Plates were incubated for $24 \mathrm{~h}$ at $37^{\circ} \mathrm{C}$ and the hemolytic activity of each isolate was evaluated as total or $\beta$-hemolysis (clear halos around the colonies), partial or $\alpha$-hemolysis (greenish halos around the colonies), or $\gamma$-hemolysis (absence of hemolysis). B. cereus ATCC27348, Escherichia coli ATCC25922, and Lactobacillus plantarum ATCC14197 were applied as positive and negative controls, respectively.

For the evaluation for gelatinase activity of the investigated strains, the approach proposed by Colombo et al. [11] was followed. For the purpose of the experiment, 1- $\mu \mathrm{L}$ aliquots of the evaluated cultures were spotted on the surface of Luria-Bertani (LB) agar (BD, Franklin Lakes, NJ, USA) supplemented with $3 \%(w / v)$ gelatin (BD). Plates were incubated at $37^{\circ} \mathrm{C}$ for $48 \mathrm{~h}$, followed by maintaining the plates at $4{ }^{\circ} \mathrm{C}$ for $4 \mathrm{~h}$. Evidence for gelatin hydrolysis was recorded based on the formation of opaque halos around the growing colonies. E. coli ATCC25922 served as a positive control, while Lb. plantarum ATCC14197 and E. faecalis HEM200 served as negative controls. 
The potential to produce biogenic amines from the evaluated strains was performed according to Bover-Cid and Holzapfel [9]. Evaluated cultures were grown at least five times consecutively to MRS broth supplemented with $0.1 \%(w / v)$ amino acid precursors for the production of biogenic amines. The biogenic amine precursors were added individually and comprised lysine, tyrosine, ornithine, and histidine (Sigma-Aldrich) and $0.005 \%(w / v)$ pyridoxal-5-phosphate (Sigma-Aldrich). The incubation was performed for $24 \mathrm{~h}$ at $37^{\circ} \mathrm{C}$, and the last transfer performed was streaked in duplicate on a modified MRS agar according to Bover-Cid and Holzapfel [9] which was supplemented with one of each biogenic amine precursor described as above $(1 \% w / v)$. All plates were incubated for 4 days at $37^{\circ} \mathrm{C}$ and the change of the color from yellow to purple was considered as a positive result for the production of a biogenic amine. E. coli ATCC25922 and Lb. plantarum ATCC14197 served as positive and negative controls, respectively.

\subsection{Antimicrobial Susceptibility Profiling}

The antimicrobial susceptibility testing for the Bacillus strains was performed according to recommendations by the Clinical and Laboratory Standards Institute (CLSI) on the Performance Standards for Antimicrobial Susceptibility Testing M45 for Bacillus spp. Using the broth micro-dilution method, minimum inhibitory concentrations (MIC) were determined for the antibiotics ampicillin, gentamycin, kanamycin, streptomycin, erythromycin, clindamycin, tetracycline, chloramphenicol (all from Sigma-Aldrich), vancomycin (Cheil Jedang Pharma Co., Republic of Korea), and ciprofloxacin (Sigma-Aldrich), which is commonly applied as an antibiotic agent in treatment of Bacillus infections (https://clsi.org/, accessed on 25 March 2020).

Cation-adjusted Mueller-Hinton broth, additionally supplemented with $5.0 \mathrm{~g} / \mathrm{L}(\mathrm{v} / \mathrm{v})$ MRS was distributed in a sterile 96-well micro-dilution plate (SPL Life Sciences, Pocheonsi, Gyeongi-do, Republic of Korea). Fifty microliters in different concentrations of each antibiotic, previously prepared to cover expected ranges of MIC values, were added to $50 \mu \mathrm{L}$ of a bacterial suspension, adjusted to approximately $10^{5} \mathrm{CFU} / \mathrm{mL}$ based on the McFarland scale. The plates were incubated for $24 \mathrm{~h}$ at $35^{\circ} \mathrm{C} \pm 1$, according to recommendations of EUCAST [34]. The MIC values, defined as the lowest concentration that completely inhibits bacterial growth, were read in a spectrophotometer and compared to the cut-off set of EUCAST. Each antibiotic was assessed in at least two individual experiments.

\subsection{Detection of Vancomycin Resistant Genes}

The DNA previously isolated from the evaluated strains was subjected to PCR analysis for investigating the presence of vancomycin resistance genes vanA (vanAB/F: $5^{\prime}-\mathrm{GTA}$ GGC TGC GAT ATT CAA AGC - 3'; vanA/R: $5^{\prime}$ - CGA TTC AAT TGC GTA GTC CAA - 3'), vanB (vanAB/F: $5^{\prime}$ - GTA GGC TGC GAT ATT CAA AGC - 3'; vanB/R: $5^{\prime}$ - GCC GAC AAT CAA ATC CTC - 3'), vanC (vanC/F: $5^{\prime}$ - ATC CAA GCT ATT GAC CCG CT - 3'; vanC/R: $5^{\prime}$-TGT GGC AGG ATC GTT TTC AT - 3'), vanD (vanD/F: $5^{\prime}$ - TGT GGG ATG CGA TAT TCA A - 3'; vanD/R: 5' - TGC AGC CAA GTA TCC GGT AA - 3'), vanE (vanE/F: 5' - TGT GGT ATC GGA GCT GCA G - 3'; vanE/R: $5^{\prime}$ - GTC GAT TCT CGC TAA TCC - 3') and vanG (vanG/F: 5' - GAA GAT GGT ACT TTG CAG GGC A - 3'; vanG/R: 5' - AGC CGC TTC TTG TAT CCG TTT T - 3') previously reported by Valledor et al. [35]. PCR products were separated on $2.0 \%(w / v)$ agarose gels in $1 \times$ TBE and visualized as described before.

\section{Results}

Based on the application of the triple layer approach, applying MRS supplemented with $2 \%$ agar as principal growth medium resulted in predominant growth of colonies with morphology typical for representatives from genus Bacillus. Preliminary screening of bacterial strains with potential antimicrobial properties against L. monocytogenes ATCC15314 resulted in selection of 21 isolates. Based on preliminary observations, all isolates were catalase positive, showed specific Bacillus colony morphology on solid media, and Grampositive, and thereby pre-identified as Bacillus spp. Additional antimicrobial activity tests 
confirmed that 12 isolates were producers of antimicrobial compounds based on activity against $L$. monocytogenes ATCC153131.

\subsection{Differentiation and Identification}

Twelve isolates with confirmed production of antimicrobial metabolites were differentiated based on fingerprinting generated by RAPD-PCR and 5 distinct clusters were identified (Figure 1). Biochemical, morphological, and physiological results were taken into account in the selection of 5 representatives out of 12 isolates for $16 \mathrm{~S}$ rRNA sequencing and specific identification of these strains. Representatives from each cluster, ST03, ST06, ST08, ST32, and ST109, were identified to belong to Bacillus velezensis, Bacillus amyloliquefaciens, and Bacillus subtilis; and named Bacillus velezensis ST03, Bacillus velezensis ST32, Bacillus amyloliquefaciens ST06, Bacillus amyloliquefaciens ST109, and Bacillus subtilis ST08.

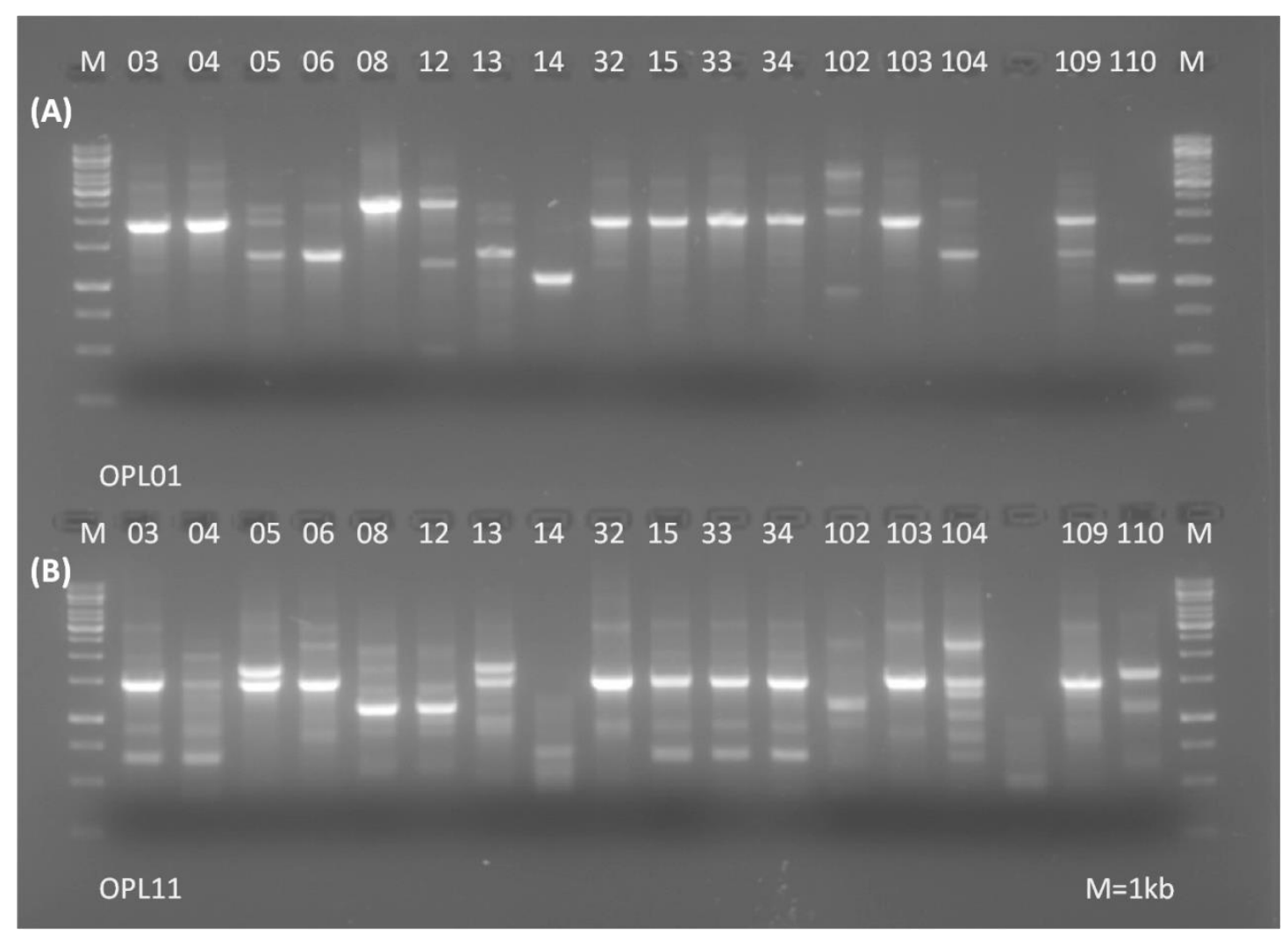

Figure 1. RAPD-PCR products generated with (A) primer OPL01 and (B) primer OPL11 for various isolates differentiated in this study; lane M: O'GeneRuler 1 kb DNA Ladder (Fermentas).

\subsection{Sugar Fermentation Profile (API50CHB) and Enzymes Production (APIZym)}

The ability of the studied Bacillus strains (ST03, ST06, ST08, ST32, and ST109) to metabolize different carbohydrates sources was evaluated based on the API50CHB test, and all tested strains were able to ferment glycerol, L-arabinose, ribose, D-xylose, D-glucose, D-fructose, D-mannose, inositol, mannitol, sorbitol, $\alpha$-methyl-D-glucosamine, amygdalin, arbutin, esculin, salicin, cellobiose, maltose, saccharose, trehalose, D-raffinose, amidon, and glycogen (Table 2). In addition, only B. amyloliquefaciens ST109 fermented L-xylose and $\alpha$-methyl-D-mannoside; B. amyloliquefaciens ST06 and ST109 galactose and $\beta$-gentiobiose, B. velezensis ST03 and ST32 and B. amyloliquefaciens ST06 and ST109 lactose, B. amyloliquefaciens ST06 and ST109 and B. subtilis ST08 melibiose and D-turanose, and B. subtilis ST08 inulin (Table 2). 
Table 2. Carbohydrate fermentation profile recorded for B. velezensis ST03, B. amyloliquefaciens ST06, B. subtilis ST08, B. velezensis ST32, and B. amyloliquefaciens ST109 based on API50CHB (BioMerieux).

\begin{tabular}{|c|c|c|c|c|c|}
\hline Carbohydrates & ST03 & ST06 & ST08 & ST32 & ST109 \\
\hline control (no carbohydrate) & - & - & - & - & - \\
\hline glycerol, L-arabinose, ribose, D-xylose, D-glucose, D-fructose, D-mannose, inositol, mannitol, sorbitol, & & & & & \\
\hline $\begin{array}{l}\alpha \text {-methyl-D-glucosamine, amygdalin, arbutin, esculin, salicin, cellobiose, maltose, saccharose, trehalose, D-raffinose, } \\
\text { amidon, glycogen }\end{array}$ & + & + & + & + & + \\
\hline L-xylose, $\alpha$-methyl-D-mannoside & - & - & - & - & + \\
\hline galactose, $\beta$-gentiobiose & - & + & - & - & + \\
\hline lactose & + & + & - & + & + \\
\hline melibiose, D-turanose & - & + & + & - & + \\
\hline inulin & - & - & + & - & - \\
\hline $\begin{array}{l}\text { erythritol, D-arabinose, adonitol, } \beta \text {-methyl-xyloside, L-sorbose, rhamnose, dulcitol, N-acetylglucosamine, melezitose, } \\
\text { xylitol, D-lyxose, D-tagatose, D-fucose, L-fucose, D-arabitol, L-arabitol, gluconate, 2-keto-gluconate, 5-keto-gluconate }\end{array}$ & - & - & - & - & - \\
\hline
\end{tabular}

+ Bacterial growth, evidence for fermenting the evaluated carbohydrate; - no bacterial growth.

Expression of different enzymes (alkaline phosphatase, esterase (C4), lipase esterase (C8), acidphosphatase, naphthol phosphohydrolase, $\alpha$-galactosidase, $\alpha$-glucosidase, and $\beta$ glucosidase) were recorded for the studied strains (ST03, ST06, ST08, ST32, and ST109) (Table 3).

Table 3. Enzyme production profile recorded for B. velezensis ST03, B. amyloliquefaciens ST06, B. subtilis ST08, B. velezensis ST32, and B. amyloliquefaciens ST109 based on APIZym (BioMerieux).

\begin{tabular}{|c|c|c|c|c|c|}
\hline Target Enzymes & ST03 & ST06 & ST08 & ST32 & ST109 \\
\hline Control & $0 *$ & 0 & 0 & 0 & 0 \\
\hline alkaline phosphatase & 5 & 3 & 3 & 3 & 3 \\
\hline esterase (C4) & 4 & 4 & 4 & 5 & 3 \\
\hline lipase esterase (C8) & 5 & 4 & 4 & 5 & 3 \\
\hline acid phosphatase & 0 & 0 & 1 & 0 & 3 \\
\hline naphthol phosphohydrolase & 3 & 3 & 3 & 3 & 3 \\
\hline$\alpha$-galactosidase & 0 & 0 & 1 & 0 & 0 \\
\hline$\alpha$-glucosidase & 3 & 3 & 5 & 3 & 3 \\
\hline$\beta$-glucosidase & 1 & 3 & 4 & 4 & 4 \\
\hline $\begin{array}{l}\text { lipase (C14), leucinearylamidase, valinearylamidase, cystinarylamidase, trypsin, } \\
\alpha \text {-chymotrypsin, } \beta \text {-galactosidase, } \beta \text {-glucuronidase, } N \text {-acetyl- } \beta \text {-glucosaminidase, } \\
\alpha \text {-mannosidase, } \alpha \text {-fucosidase }\end{array}$ & 0 & 0 & 0 & 0 & 0 \\
\hline
\end{tabular}

* 3-5: Strong enzymatic activity, 1-2: Weak enzymatic activity. 0: No evidence for enzymatic activity (interpretation was performed in accordance with the manual provided by BioMerieux).

\subsection{Detection of Bacteriocin and Other Antimicrobial Genes}

DNA samples obtained from the studied strains (ST03, ST06, ST08, ST32, and ST109) generated positive results for the presence of lichenicidin in B. subtilis ST08, iturin in B. velezensis ST03, B. amyloliquefaciens ST06 and B. amyloliquefaciens ST109, subtilosin in B. velezensis ST03, B subtilis ST08 and B. amyloliquefaciens ST109, and surfactin in all studied bacillus strains. No evidence based on the PCR reactions wasrecorded for the presence of Class IIa bacteriocins thuricin, coagulin, orpediocin PA-1 (Table 4).

Preliminary results evaluating bacterial growth and production of bacteriocins suggested that Luria-Bertani (LB) and nutrition broth can support bacterial growth; however, bacteriocin production was recorded only at $200 \mathrm{AU} / \mathrm{mL}$ or lower for the studied strains. Higher levels of expressed bacteriocins, between 800 and $1600 \mathrm{AU} / \mathrm{mL}$, were recorded when strains were cultured in MRS broth. Based on these observations, MRS was selected as the growth medium for evaluation of bacteriocinogenic properties of B. velezensis ST03, ST32, B. amyloliquefaciens ST06 and ST109, and B. subtilis ST08. The selected strains were found to produce antimicrobial metabolites at an activity level of $800 \mathrm{AU} / \mathrm{mL}$ for $B$. velezensis ST03, B. amyloliquefaciens ST06, and B. velezensis ST32, and $1600 \mathrm{AU} / \mathrm{mL}$ for B. subtilis ST08 and B. amyloliquefaciens ST109, as determined against L. monocytogenes ATCC15313. Moreover, the spectrum of activity of these antimicrobial metabolites produced by strains ST03, ST06, ST08, ST32, and ST109 was determined against selected test organisms obtained from different collections (Table 1). 
Table 4. Spread of antimicrobials, virulence- and vancomycin-resistant related genes in DNA obtained from $B$. velezensis ST03, B. amyloliquefaciens ST06, B. subtilis ST08, B. velezensis ST32, and B. amyloliquefaciens ST109.

\begin{tabular}{|c|c|c|c|c|c|}
\hline & $\begin{array}{c}\text { Bacillus } \\
\text { velezensis ST03 }\end{array}$ & $\begin{array}{c}\text { Bacillus } \\
\text { amyloliquefaciens ST06 }\end{array}$ & Bacillus subtilis ST08 & $\begin{array}{c}\text { Bacillus } \\
\text { velezensis ST32 }\end{array}$ & $\begin{array}{c}\text { Bacillus } \\
\text { amyloliquefaciens ST109 }\end{array}$ \\
\hline \multicolumn{6}{|c|}{ Antimicrobials related genes } \\
\hline Class IIa bacteriocins & - & - & - & - & - \\
\hline Lichenicidin & - & - & + & - & - \\
\hline Thuricin & - & - & - & - & - \\
\hline Surfactin & + & + & + & + & + \\
\hline Iturin & + & + & - & - & + \\
\hline Coagulin & - & - & - & - & - \\
\hline Subtilosin & + & - & + & - & + \\
\hline Pediocin PA-1 & - & - & - & - & - \\
\hline \multicolumn{6}{|l|}{ Virulence genes } \\
\hline$h b l \mathrm{~A}$ & - & - & - & - & - \\
\hline$h b l \mathrm{~B}$ & - & - & - & - & - \\
\hline$h b l \mathrm{C}$ & - & - & + & - & - \\
\hline nheA & - & - & - & - & - \\
\hline nhe B & - & - & - & - & + \\
\hline nheC & - & - & + & - & - \\
\hline \multicolumn{6}{|c|}{ Vancomycin resistance genes } \\
\hline $\operatorname{van} \mathrm{A}$ & - & - & - & - & - \\
\hline $\operatorname{van} \mathrm{B}$ & - & - & - & - & - \\
\hline $\operatorname{van} \mathrm{C}$ & - & - & - & - & - \\
\hline $\operatorname{van} \mathrm{D}$ & - & - & - & - & - \\
\hline $\operatorname{van} \mathrm{E}$ & - & - & - & - & - \\
\hline $\operatorname{van} \mathrm{G}$ & - & - & - & - & - \\
\hline
\end{tabular}

+ Detection of targeted gen; - absence of targeted gene.

All tested strains in this study (ST03, ST06, ST08, ST32, and ST109) remained partially active after proteolytic enzyme treatment, albeit with reduced inhibition zones compared to the controls (non-treated supernatants) suggesting that antimicrobial activity may be related to a combination of antimicrobial protein (bacteriocin) in a combination with a non-proteinaceous antimicrobial molecular structure, or partial resistance of bacteriocins (antimicrobial peptide) to the effect of applied specific proteolytic enzymes. PCR analysis of the DNA from strains ST03, ST06, ST08, ST32, and ST109 showed evidence for the presence of a surfactin-related gene in all tested Bacillus spp. strains in this study.

\subsection{Stability of the Antimicrobial Substances-Effect of $p H$, Temperature, and Chemicals}

Antimicrobials produced by the strains ST03, ST06, ST08, ST32, and ST109 generally presented stability of the activity after being exposed to the effect of different $\mathrm{pH}$ levels ( $\mathrm{pH}$ of $2.0,4.0,6.0,8.0$, and 10.0) and temperatures $\left(30,37,45,60,80\right.$, and $100^{\circ} \mathrm{C}$, respectively, up to $120 \mathrm{~min}$, and at $121^{\circ} \mathrm{C}$ for $20 \mathrm{~min}$ ). In addition, their stability was not affected notably in the presence of $10 \mathrm{mg} / \mathrm{mL}$ of Tween 20, Tween 80, NaCl, SDS, EDTA, milk, or glycerol, respectively.

3.5. In Vitro Hemolytic Activity and Presence of Genes Related to Hemolysin and Non-Hemolytic Enterotoxin Virulence Factors; Gelatinase and Biogenic Amine Production

Strains ST03, ST06, ST08, ST32, and ST109 generated different results and were evaluated for their hemolysis behavior on blood agar plates. ST03, ST09, and ST32 were tested positive for $\beta$-hemolysis. On the other side, results from PCR analysis targeting $h b l \mathrm{~A}, h b l \mathrm{~B}$, $h b l \mathrm{C}$, nhe A, nhe B, and nhe $\mathrm{C}$ showed that strains B. subtilis ST08 could carry $h b l \mathrm{C}$ and nheC and B. amyloliquefaciens ST109 was positive for nheB (Table 2).

From the tested strains ST03, ST06, ST08, ST32, and ST109, only ST109 generated positive results for gelatinase activity. However, for strains ST03, ST06, ST08, ST32, and ST109 we recorded production of all 4 tested biogenic amines, histamine, tyramine, putrescine, and cadaverine, derived from histidine, tyrosine, ornithine, and lysine, respectively.

\subsection{Antibiotic Resistance}

Based on PCR analysis, no evidence for the investigated vancomycin resistance genes (van $A, \operatorname{van} B, \operatorname{van} C, \operatorname{van} D, \operatorname{van} E$, and $\operatorname{van} G)$ could be recorded in the studied Bacillus strains 
(Table 2). Based on the in vitro test with vancomycin, all tested Bacillus strain were susceptible with cut-off values of $0.5 \mu \mathrm{g} / \mathrm{mL}$, suggesting their susceptibility according to the recommendations of CLSI $(\leq 4 \mu \mathrm{g} / \mathrm{mL})$ and EFSA $(4 \mu \mathrm{g} / \mathrm{mL})$ (Table 5$)$.

Table 5. Antibiotic susceptibility for B. velezensis ST03, B. amyloliquefaciens ST06, B. subtilis ST08, B. velezensis ST32, and B. amyloliquefaciens ST109.

\begin{tabular}{|c|c|c|c|c|c|c|c|}
\hline \multirow{2}{*}{ Antibiotics } & \multicolumn{5}{|c|}{ Experimental MIC $(\mu \mathrm{g} / \mathrm{mL})$ Values for Strains } & \multirow{2}{*}{$\begin{array}{l}\text { CLSI Cut-Offs (S, I, R) for } \\
\text { Bacillus spp. }(\mu \mathrm{g} / \mathrm{mL})\end{array}$} & \multirow{2}{*}{$\begin{array}{l}\text { EFSA Cut-Offs for } \\
\text { Bacillus spp. }(\mu \mathrm{g} / \mathrm{mL})\end{array}$} \\
\hline & ST03 & ST06 & ST08 & ST32 & ST109 & & \\
\hline ampicillin & 128 & 16 & $\leq 0.25$ & 128 & 64 & $\leq 0.25,-, \geq 0.5$ & n.r. \\
\hline vancomycin & 0.5 & 0.5 & 0.5 & 0.5 & 0.5 & $\leq 4, * *$ & 4 \\
\hline gentamycin & 0.5 & 0.5 & 2 & 0.5 & 0.5 & $\leq 4,8, \geq 16$ & 4 \\
\hline kanamycin & 2 & 2 & 8 & 4 & 16 & $\leq 1,2, \geq 4$ & 8 \\
\hline streptomycin & 8 & 8 & 64 & 8 & 2 & $\begin{array}{l}\text { n.r. } \\
\text { n. }\end{array}$ & 8 \\
\hline erythromycin & 2 & 2 & 2 & 2 & 2 & $\leq 0.5,1-2, \geq 4$ & 4 \\
\hline clindamycin & 0.5 & $\leq 0.25$ & 1 & 0.5 & 0.5 & $\leq 0.5,1-2, \geq 4$ & 4 \\
\hline tetracycline & 4 & 4 & 4 & 8 & $\leq 0.25$ & $<4,8,>16$ & 8 \\
\hline chloramphenicol & 4 & 2 & 4 & 1 & 2 & $<8,16,>32$ & 8 \\
\hline ciprofloxacin & $\leq 0.25$ & $\leq 0.25$ & $\leq 0.25$ & $\leq 0.25$ & $\leq 0.25$ & $\leq 1,2, \geq 4$ & n.r. \\
\hline
\end{tabular}

S: Sensitive; I: Intermediate; R: Resistant; ${ }^{*}$ no set values; n.r.: Antibiotic not listed in the recommendations of cited agency.

Results of the performed in vitro tests for determination of interaction of the studied Bacillus strains and selected antibiotics are summarized in Table 5. All tested Bacillus strains (ST03, ST06, ST08, ST32, and ST109) were susceptible to vancomycin, gentamycin, chloramphenicol, and ciprofloxacin according to breakpoint values recommendations of CLSI and EFSA (Table 5). The other tested antibiotics showed different interference with activity of the studied Bacillus strains. Only strain ST08 showed susceptibility to ampicillin with MIC value of $\leq 0.25 \mu \mathrm{g} / \mathrm{mL}$, while the other Bacillus strains were resistant to ampicillin. All strains were resistant to kanamycin according to EFSA (with a cut-off value of $8 \mu \mathrm{g} / \mathrm{mL}$ ), however, intermediate for ST03 and ST06 according to CLSI (with cut-off of $2 \mu \mathrm{g} / \mathrm{mL}$ ). Based on the EFSA recommendations, only ST109 was susceptible to streptomycin and the other strains were resistant. In addition, according to the recommendations of EFSA, the studied strains were susceptible to clindamycin and tetracycline, but according to CLSI, ST08 was intermediate to clindamycin (with cut-off of $1-2 \mu \mathrm{g} / \mathrm{mL}$ ), and ST109 was intermediate to tetracycline (with cut-off of $8 \mu \mathrm{g} / \mathrm{mL}$ ). All tested strains were classified as intermediate to the effect of erythromycin (with cut-off of $1-2 \mu \mathrm{g} / \mathrm{mL}$ ) (Table 5).

\section{Discussion}

Preliminary screening of bacterial strains with anti-listerial activity resulted in selection of 21 isolates. Selection of L. monocytogenes as principal test organism in screening for producer(s) of antimicrobial metabolites strains was based on relevance of that food-borne pathogen for human and other animals' health. L. monocytogenes is highly contagious microorganisms, able to survive in low $\mathrm{pH}$ and under refrigeration, and was listed as having "zero tolerance" for different food products and by several countries [6,32,35]. All selected potential bacteriocin producers were pre-identified as Bacillus spp. Different Bacillus strains are well known as producers of an arsenal of antimicrobial metabolites, including bacteriocins, antibiotics, and enzymes [13-19,36-39]. These features are frequently explored for industrial microbiological applications, and different Bacillus strains are used for large scale production of antibiotics and enzymes $[13,15,16]$. Despite the fact that bacteriocin production by Bacillus spp. is well documented [18,19,36-39], industrial production of such bacteriocins has not been explored yet. On the other side, Bacillus starter cultures are well known and applied in the production of different fermented food products in different regions of Asia and Africa, including soybean paste [40], bikalga, an alkaline fermented food [40], lanhouin, a traditional fish-based condiment from West Africa [41], kimchi and chongkukjang from Korean Peninsula [42], and natto, soybean products from Japan [43,44]. Some of these Bacillus starter cultures are described as producers of bacteriocin [18,19] and antibiotics [15]. On the other hand, application of antimicrobial metabolites produced by Bacillus spp. in the control of spoilage or pathogenic organisms is well explored in the food 
industry. However, scientific questions are related to the identification and characterization of the produced antimicrobials and their role in the effective control of spoilage organisms and pathogens.

From 21 initially selected potential bacteriocin producers, 12 isolates with confirmed production of antimicrobial metabolites were differentiated based on fingerprinting generated by RAPD-PCR, grouped in 5 distinct clusters (Figure 1) and were identified as Bacillus velezensis ST03, Bacillus velezensis ST32, Bacillus amyloliquefaciens ST06, Bacillus amyloliquefaciens ST109, and Bacillus subtilis ST08. Strains belonging to B. velezensis and B. subtilis subsp. subtilis were previously isolated from kimchi [25,45], even if their role in the production of this fermented cabbage product is still not very well established [25]. Bacillus spp. are generally described as soil-related organisms, and their presence in kimchi may most probably be the consequence of low hygienic practices in the preparation process. On other side, Bacillus spp. were described as important microbial cultures, taking part in the fermentation processes of traditional fermented food products of plant origin [25,40,45,46]. Still, the putative role of Bacillus strains in the fermentation process of kimchi merits more precise scientific evaluation.

The ability of the studied Bacillus strains to metabolize different carbohydrate sources was evaluated based on the API50CHB test (Table 2). These results represent additional relevant information for confirmation differences between the evaluated strains. Furthermore, the carbohydrate fermentation profile can be applied as important information in the design of effective and low-cost growth-production media for the production of bacteriocins in future potential biotechnological applications.

Expression of different enzymes were recorded for the studied strains by APIZym test (Table 3). Bacillus spp. are known for their biologically active molecules, including enzymatic production abilities, and this is well explored by biotechnological industry [13-17]. Specific enzymatic activity can be discussed both as a positive and negative feature. Montel et al. [47] pointed out that aldehydes, alcohols, and acids derived from the breakdown of some amino acids (leucine, valine, phenylalanine, and methionine) have a minimal effect on the sensory quality (i.e., taste and smell) of the fermented products, but can be more relevant in the reduction of allergenic characteristics of some proteins, and, related to this, can be considered as beneficial. El Mecherfi et al. [48] suggested the production of proteolytic and lipolytic enzymes is to be beneficial in the reduction of allergenicity in dairy, meat, and even gluten in cereal-based products. Park et al. [49] evaluated the production of lipolytic enzymes of Bacillus strains with regard to their potential application in the development of anti-obesity probiotics. George [50] pointed to the fact that $\beta$-glucuronidase is a carcinogenic bacterial enzyme that exerts negative effects on the liver and that such enzymatic activity needs to be considered with special attention to the safety evaluation of bacterial cultures.

Based on the bio-molecular approach, studied strains (ST03, ST06, ST08, ST32, and ST109) generated positive results for the potential production of lichenicidin in B. subtilis ST08, iturin in B. velezensis ST03, B. amyloliquefaciens ST06, and B. amyloliquefaciens ST109, subtilosin in B. velezensis ST03, B subtilis ST08, and B. amyloliquefaciens ST109, and surfactin in all studied Bacillus strains (Table 2). An overview of the literature showed that Bacillus spp. can be multi-antimicrobial producers. Yang and Chang [51] reported on two bacteriocins of 2.4 and $4.5 \mathrm{kDa}$ produced by B. subtilis MJP1, isolated from meju. Wu et al. [52] investigated two bacteriocins produced by B. subtilis JM4 isolated from soil in Korea, and found a molecular mass of 1422.71 and $1422.65 \mathrm{Da}$, respectively, and differences only in the seventh amino acid, as determined after purification, mass spectrometry, and amino-acid sequencing. Salazar et al. [53] reported on two bacteriocins produced by B. amyloliquefaciens ELI149 isolated from soil in Mexico.

The most widely studied bacteriocins produced by different representatives of the genus Bacillus are subtilin $[54,55]$ and subtilosin A [56,57]. Some reports focused on the application of bacteriocins in the control of food spoilage and pathogenic organisms, with producing strains belonging to B. subtilis, B. cereus, B. thuringiensis, and other Bacillus spp. [58,59]. Most bacte- 
riocins produced by Bacillus spp. strains were classified as class I (lantibiotics), with some exceptions of a class II pediocin-like bacteriocin, such as coagulin [60].

The ability to produce and express antimicrobial metabolites, including antimicrobial peptides, needs to be evaluated as an adaptive process, giving selective benefits for better survival and colonization opportunity to the producing strain. This adaptive ecological specificity also applies to representative strains of Bacillus spp. Generally, as part of the soil-plant ecosystem, Bacillus spp. have to compete with several other groups of organisms, and an arsenal of different antimicrobial metabolites can provide competitive benefits to a producing strain, resulting in domination in a mixed culture. However, from a metabolic point, additional research needs to be performed in order to clarify which specific antimicrobials are expressed and/or in what proportions, based on purification and mass spectrometry identification and/or following the specific RNA expression related to appropriate genes involved in the production of reported antimicrobials. Thereby, it should also be considered that environmental conditions may play a regulatory role in the expression of these genes, as well as investigating how these processes are regulated. As suggested by Chikindas et al. [6] investigations should also be directed to information on activation of these genes either by inhibitory metabolites or whether these bacteriocins play an additional role in the life cycle of the producer organism(s).

Studied strains were able to express bacteriocins between 800 and $1600 \mathrm{AU} / \mathrm{mL}$ when cultured in MRS broth at $30^{\circ} \mathrm{C}$ for $24 \mathrm{~h}$, as determined against L. monocytogenes ATCC15313 and against some other test organisms obtained from different collections (Table 1). Most of the studied antimicrobials showed a narrow spectrum of activity, generally inhibiting only a few of the test strains. The specificity in the spectrum of activity is one of the principal differences between these two classes of antimicrobial agents [61,62]. Therefore, these results suggest that the evaluated strains are expressing bacteriocins rather than antibiotics.

The protein nature is a primary characteristic of bacteriocins, and by definition they are considered as polypeptides $[6,7,32]$. However, while some classes of antibiotics are proteins by nature as well, their final formation is by additional posttranslational modification [61]. In addition, they are characterized as peptides with significantly higher molecular mass compared to other bacteriocins. Taking into consideration that preparation of the cell-free supernatant was also included, heat treatment for $10 \mathrm{~min}$ at $80^{\circ} \mathrm{C}$ by larger proteins was supposed to be inactivated. Thus, the antimicrobials produced by strains ST03, ST06, ST08, ST32, and ST109 may be considered as typical bacteriocins. However, all tested strains in this study (ST03, ST06, ST08, ST32, and ST109) remained active after proteolytic enzyme treatment, albeit with reduced inhibition zones compared to the controls (non-treated supernatants) pointing that antimicrobial activity may be related to a non-proteinaceous molecular structure, or partial resistance of bacteriocins (antimicrobial peptide) to the effect of applied specific proteolytic enzymes. PCR analysis of the DNA from strains ST03, ST06, ST08, ST32, and ST109 showed evidence for the presence of a surfactin related gene in all tested Bacillus spp. strains in this study. Most probably the set strains may express surfactin, a substance that has been previously shown to have antimicrobial activity [29]. Moreover, this is not surprising, since Bacillus spp. are known for their ability to produce a variety of bioactive metabolites [13-17].

For scientific and technological information, the stability of antimicrobial compounds at different temperatures, levels of $\mathrm{pH}$, and in the presence of chemicals is a relevant property in the characterization of newly isolated metabolites. Interactions with surfactants and chelating agents can provide information related to the structures of proteins. Moreover, interaction with common chemical additives applied in the food industry can provide information about the relevance of application of specific antimicrobial metabolites in food systems. Thereby, $\mathrm{pH}$ and temperature stability are important parameters for the practical application of such antimicrobials as food additives and preservatives, and are important characteristics in the development of antimicrobials for human and veterinary applications. Antimicrobials produced by the strains ST03, ST06, ST08, ST32, and ST109 generally presented stability of the activity after being exposed to the effect of different $\mathrm{pH}$ levels 
( $\mathrm{pH}$ of $2.0-10.0)$ and temperatures $\left(30-100{ }^{\circ} \mathrm{C}\right.$, respectively, up to $120 \mathrm{~min}$, and at $121^{\circ} \mathrm{C}$ for $20 \mathrm{~min}$ ). In addition, their stability was not affected notably in the presence of $10 \mathrm{mg} / \mathrm{mL}$ of Tween 20, Tween 80, NaCl, SDS, EDTA, milk, or glycerol, respectively. Stability in the presence of different chemicals, exposure to temperatures, and various levels of $\mathrm{pH}$ has been reported for numerous bacteriocins produced by LAB and Bacillus spp. [54-57].

Only ST03, ST09, and ST32 tested positive for $\beta$-hemolysis. Moreover, results from PCR analysis targeting $h b l \mathrm{~A}, h b l \mathrm{~B}, h b l \mathrm{C}$, nhe A, nhe $\mathrm{B}$, and $n h e \mathrm{C}$ showed that strains $B$. subtilis ST08 can carry $h b l C$ and $n h e C$ and B. amyloliquefaciens ST109 was positive for nheB (Table 4). However, in order to be considered as positive for expression of hemolysin, a strain needs to be positive for $h b l \mathrm{~A}, h b l \mathrm{~B}$, and $h b l \mathrm{C}$. For expression of non-hemolytic enterotoxin(s), a strain needs to carry nhe $\mathrm{A}, n h e \mathrm{~B}$, and $n h e \mathrm{C}$ genes. Safety evaluation is a priority in the evaluation of beneficial organisms. As part of these tests, hemolytic activity is considered as an important virulence factor and a key in the safety evaluation of newly isolated bacterial cultures towards their characterization as beneficial organisms. Hemolytic activity can play a role in pathogenesis of harmful bacteria and was associated with anemia or edema in the host based on facilitating acquisition of iron to the pathogen [63].

Only ST109 from all five tested strains generated positive results for gelatinase activity. Production of the gelatinase enzyme is considered as a virulence factor in the evaluation of safety of beneficial organisms, being related to the ability to hydrolyze collagens and thereby maybe directly involved in the initiation of inflammatory responses [64]. Barbosa et al. [64] reported in a study evaluating 76 enterococcal cultures that high numbers of them $(26 \%)$ were gelatinase producers. Franz et al. [65] previously reported similar observations in the evaluation of safety for different beneficial cultures.

Biogenic amines are typically formed as decarboxylation products of amino acids. For strains ST03, ST06, ST08, ST32, and ST109, we have recorded production of all 4 tested biogenic amines, histamine, tyramine, putrescine, and cadaverine, derived from histidine, tyrosine, ornithine, and lysine, respectively. Production of biogenic amines is an important safety concern, and is frequently associated with the presence of food spoilage organisms [66,67], but are also commonly produced during fermentation [68,69]. Uptake of high levels of biogenic amines, and especially of histamine and tyramine, can result in health issues and be associated with severe symptoms such as abdominal pain, diarrhea, headache, hypertension, migraine, and possibly other neurological complications [70]. Characterization of the strains ST03, ST06, ST08, ST32, and ST109 as producers of biogenic amines may compromise their application as beneficial cultures. On the other hand, appropriate detection and quantification of the levels of biogenic amines need to be clearly assessed in the products (kimchi) from where these strains were isolated in order to compare levels of the produced biogenic amines in the fermented food products with the international safety standards.

Biogenic amines are considered as toxic compounds and their levels in food products should not exceed specific levels (histamine, $100 \mathrm{mg} / \mathrm{kg}$; tyramine, 100-800 mg/kg; $\beta$-phenylethylamine, $30 \mathrm{mg} / \mathrm{kg}$; total biogenic amines, $1000 \mathrm{mg} / \mathrm{kg}$ ) [71,72]. Some polyamines such as putrescine and cadaverine were reported to potentially have toxic consequences when present in food [71], especially for sensitive persons. The ability of the specific strain to produce biogenic amines is genetically determined; however, it is dependent on the specific growth conditions and presence of precursors for this production. Levels of expression of specific genes by studied strains and levels of accumulation of biogenic amines in the food products need to be evaluated in the future to confirm if this will generate a concern issues related to safety of studied strains.

Protein metabolism and formation of different free amino acids and/or small peptides were intensively studied in different groups of microorganisms and their role as spoilage or beneficial processes were evaluated [73-75]. Atanasova et al. [73] reported on the role of starter cultures in the formation and free amino acids and different bioactive peptides in cheeses fermented with Lactobacillus delbrueckii subsp. bulgaricus and Streptococcus thermophilus; Stribny et al. [74] detailed the evaluated role of Saccharomyces spp. in the 
production of aroma-related higher alcohols and acetate esters in metabolism of amino acid precursors; Perea-Sanz et al. [75] investigated the involvement of Debaryomyces hansenii in the production of volatile sulfur compounds from sulfur amino acids and the related metabolic pathway in different strains from food origins. Different bacterial cultures can play an essential role as starters in the formation of organoleptic characteristics of the final products; however, they can be stated as spoilage, when they were leading to formation of unpleasant or toxic metabolites, including different sulfur compounds or biogenic amines.

Some of types of kimchi can contain additional ingredients, and high levels of proteins and free amino acids can be recorded, and as consequence of fermentation processes, accumulation of biogenic amines may occur during kimchi preparation [76]. Kimchi is a highly popular side dish in the Korean Peninsula and, besides different beneficial properties, its safety evaluation has been the subject of different studies, including the presence of biogenic amines and their quantification in the final, ready-to-eat products [77-80].

No evidence for the presence of $\operatorname{van} A, \operatorname{van} B, \operatorname{van} C, \operatorname{van} D$, $\operatorname{van} E$, or $\operatorname{van} G$ was recorded in the studied Bacillus strains (Table 4). Based on the in vitro test with vancomycin, all tested Bacillus strains were susceptible with cut-off values of $0.5 \mu \mathrm{g} / \mathrm{mL}$, suggesting their susceptibility according to the recommendations of CLSI $(\leq 4 \mu \mathrm{g} / \mathrm{mL})$ and EFSA $(4 \mu \mathrm{g} / \mathrm{mL})$ (Table 5). Moreover, additional results regarding the interaction of the studied Bacillus strains and selected antibiotics are summarized in Table 5 .

Kang et al. [81] reported on the isolation of LAB from kimchi and the identification of high levels of tetracycline resistance. Ten out of 50 different batches of kimchi were sources of isolation of antibiotic-resistant LAB with MICs of tetracycline ranging between 25 and up to higher than $100 \mu \mathrm{g} / \mathrm{mL}$, in addition to the identification of specific genetic determinants as well [81]. Kang et al. [81] even alarmed that "kimchi can be considered as a potential vehicle for the spread of antibiotic-resistant lactic acid bacteria along the food chain to the consumers". Antibiotic resistance is a highly relevant topic in the safety evaluation of beneficial organisms. The possible spread of antibiotic-resistant genes between beneficial organisms and pathogens or other inhabitants of the gastro intestinal tract (GIT) is a justified argument in discussing the safety features of probiotics and starter cultures. However, Suvorov [82] pointed out that scenarios of horizontal transfer of antibiotics resistance genes in Enterococcus spp. are most probably somewhat exaggerated, and deeper studies on this topic need to be conducted. On the other side, present knowledge is pointing to the fact that strains carrying antibiotic resistance factors need to be considered as a potential hazard, and according EFSA and CLSI recommendations, such strains should not be recommended for application as starter cultures or as live probiotics.

\section{Conclusions}

Different bacteriocinogenic Bacillus strains were isolated from kimchi. Bacteriocin production is generally considered as a beneficial property by which starter cultures may have selective advantage in a mixed population for conquering an ecological niche. This may also include inhibition and elimination of sensitive pathogenic bacterial strains. However, when bacteriocinogenic strains are characterized to carry virulence or antibiotic resistance determinants, or found to possess virulence characteristics, then production of antimicrobial peptides may be considered as enhancing factors of virulence potential. The presence of strains with hemolytic activity in kimchi needs to be regarded as undesired and a potential health hazard to the consumers. On other side, antimicrobial properties of the strains may serve as basis for the development of appropriate biotechnological processes, and for exploring the application of the expressed antimicrobials.

Author Contributions: Concept: S.D.T.; experimental work: J.I.I.F., J.E.V.B., S.D.T.; data analysis: S.D.T.; funds: W.H.H.; writing of the manuscript: S.D.T.; corrections and editing: W.H.H., S.D.T. All authors have read and agreed to the published version of the manuscript. 
Funding: This research was funded by grants from the National Research Foundation (NRF) funded by the Ministry of Science \& ICT (NRF-2016M3A9A5923160 and NRF-2018M3A9F3021964), Seoul, Republic of Korea.

Data Availability Statement: All data generated or analyzed during this study are included in this published article and comply with research standards.

Acknowledgments: Grants from the National Research Foundation (NRF) were funded by the Ministry of Science \& ICT (NRF-2016M3A9A5923160 and NRF-2018M3A9F3021964), Seoul, Republic of Korea. The authors acknowledge the support from Handong Global University, Pohang, Republic of Korea. Special thanks to Sungmin Jung, Chaerin Woo, and Samantha Joy D. Valledor, students of Handong Global University, Pohang, Republic of Korea, for technical assistance.

Conflicts of Interest: The authors declare no conflict of interest.

\section{References}

1. Ouoba, L.I.; Diawara, B.; Amoa-Awua, W.K.; Traoré, A.S.; Møller, P.L. Genotyping of starter cultures of Bacillus subtilis and Bacillus pumilus for fermentation of African locust bean (Parkia biglobosa) to produce Soumbala. Int. J. Food Microbiol. 2004, 90, 197-205. [CrossRef]

2. Aliakbarpour, H.R.; Chamani, M.; Rahimi, G.; Sadeghi, A.A.; Qujeq, D. The Bacillus subtilis and lactic acid bacteria probiotics influences intestinal mucin gene expression, histomorphology and growth performance in broilers. Asian Australas. J. Anim. Sci. 2012, 25, 1285-1293. [CrossRef]

3. Tamang, J.P.; Watanabe, K.; Holzapfel, W.H. Diversity of microorganisms in global fermented foods and beverages. A review. Front. Microbiol. 2016, 7, 377. [CrossRef] [PubMed]

4. Encyclopedia Britannica. 2008. Available online: https:/ /www.britannica.com/ (accessed on 25 March 2020).

5. Jung, J.Y.; Lee, S.H.; Kim, J.M.; Park, M.S.; Bae, J.-W.; Hahn, Y.; Madsen, E.L.; Jeon, C.O. Metagenomic analysis of kimchi, a traditional Korean fermented food. Appl. Environ. Microbiol. 2011, 77, 2264-2274. [CrossRef]

6. Chikindas, M.L.; Weeks, R.; Drider, D.; Chistyakov, V.A.; Dicks, L.M. Functions and emerging applications of bacteriocins. Curr. Opin. Biotechnol. 2018, 49, 23-28. [CrossRef]

7. Todorov, S.D.; Franco, B.D.G.M.; Tagg, J.R. Bacteriocins of Gram positive bacteria having activity spectra extending beyond closely-related species. Benef. Microbes 2019, 10, 315-328. [CrossRef] [PubMed]

8. Syamaladevi, R.M.; Tang, J.; Villa-Rojas, R.; Sablani, S.; Carter, B.; Campbell, G. Influence of water activity on thermal resistance of microorganisms in low-moistre foods: A review. Compr. Rev. Food Sci. Food Saf. 2016, 15, 353-370. [CrossRef]

9. Bover-Cid, S.; Holzapfel, W.H. Improved screening procedure for biogenic amine production by lactic acid bacteria. Int. J. Food Microbiol. 1999, 53, 33-41. [CrossRef]

10. Dos Anjos, T.R.; Cavicchioli, V.Q.; Lima, J.A.S.; Vasconcellos, A.N.; Vaz, A.C.N.; Rossi, G.A.M.; Campos-Galvão, M.E.M.; Todorov, S.D.; Mathias, L.A.; Schocken-Iturrino, R.P.; et al. Unsatisfactory microbiological aspects of UHT goat milk, soy milk and dairy beverage of goat milk and soy protein: A public health issue. Food Sci. Technol. 2019, 40, 349-354. [CrossRef]

11. Colombo, M.; Nero, L.A.; Todorov, S.D. Safety profile of beneficial lactic acid bacteria isolated from dairy systems. Braz. J. Microbiol. 2020, 51, 787-795. [CrossRef]

12. Perin, L.M.; Miranda, R.O.; Todorov, S.D.; Franco, B.D.G.M.; Nero, L.A. Virulence, antibiotic resistance and biogenic amines of bacteriocinogenic lactococci and enterococci isolated from goat milk. Int. J. Food Microbiol. 2014, 185, 121-126. [CrossRef]

13. Priest, F.G. Extracellular enzyme synthesis in the genus Bacillus. Bacteriol. Rev. 1977, 41, 711-753. [CrossRef] [PubMed]

14. Barg, H.; Malten, M.; Jahn, M.; Jahn, D. Protein and vitamin production in Bacillus megaterium. In Microbial Processes and Products. Methods in Biotechnology; Barredo, J.L., Ed.; Humana Press: Totowa, NJ, USA, 2005; Volume 18. [CrossRef]

15. Stein, T. Bacillus subtilis antibiotics: Structures, syntheses and specific functions. Mol. Microbiol. 2005, 56, 845-857. [CrossRef] [PubMed]

16. Latorre, J.D.; Hernandez-Velasco, X.; Wolfenden, R.E.; Vicente, J.L.; Wolfender, A.D.; Menconi, A.; Bielke, L.R.; Hargis, B.M.; Tellez, G. Evaluation and selection of Bacillus species based on enzyme production, antimicrobial activity, and biofilm synthesis as direct-fed microbial candidates for poultry. Front. Vet. Sci. 2016, 3, 95. [CrossRef] [PubMed]

17. Daliri, E.B.; Oh, D.H.; Lee, B.H. Bioactive Peptides. Foods 2017, 6, 32. [CrossRef] [PubMed]

18. Field, D.; Cotter, P.D.; Hill, C.; Ross, R.P. Bioengineering Lantibiotics for therapeutic success. Front. Microbiol. $2015,6,1363$. [CrossRef] [PubMed]

19. Khatri, I.; Sharma, G.; Subramanian, S. Composite genome sequence of Bacillus clausii, a probiotic commercially available as Enterogermina ${ }^{\circledR}$, and insights into its probiotic properties. BMC Microbiol. 2019, 19, 307. [CrossRef]

20. Hongu, N.; Kim, A.S.; Suzuki, A.; Wilson, H.; Tsui, K.C.; Park, S. Korean kimchi: Promoting healthy meals through cultural tradition. J. Ethn. Foods 2016, 4, 172-180. [CrossRef]

21. Spencer, R.C. Bacillus anthracis. J. Clin. Pathol. 2003, 56, 182-187. [CrossRef] [PubMed]

22. Messelhäußer, U.; Ehling-Schulz, M. Bacillus cereus-A multifaceted opportunistic pathogen. Curr. Clin. Microbiol. Rep. 2018, 5, 120-125. [CrossRef] 
23. Baccigalupi, L.; Ricca, E.; Ghelardi, E. Non-LAB probiotics: Spore formers. In Probiotics and Prebiotics: Current Research and Future Trends; Venema, K., do Carmo, A.P., Eds.; Caister Academic Press: Poole, UK, 2015; pp. 93-104.

24. Elshaghabee, F.M.F.; Rokana, N.; Gulhane, R.D.; Sharma, C.; Panwar, H. Bacillus as potential probiotics: Status, concerns, and future perspectives. Front. Microbiol. 2017, 8, 1490. [CrossRef]

25. Lee, H.-W.; Yoon, S.-R.; Kim, S.-J.; Lee, H.M.; Lee, J.Y.; Lee, J.-H.; Kim, S.H.; Ha, J.-H. Identification of microbial communities, with a focus on foodborne pathogens, during kimchi manufacturing process using culture-independent and -dependent analyses. LWT Food Sci. Technol. 2016, 81, 153-159. [CrossRef]

26. Senesi, S.; Celandroni, F.; Tavanti, A.; Ghelardi, E. Molecular characterization and identification of Bacillus clausii strains marketed for use in oral bacteriotherapy. Appl. Environ. Microbiol. 2001, 67, 834-839. [CrossRef]

27. De Vos, P.; Garrity, G.M.; Jones, D.; Kreig, N.R.; Ludwig, W.; Rainey, F.A.; Schleifel, K.-H.; Whitman, W.B. Bergey's Manual of Systematic Bacteriology; The Firmicutes; Wiley Publishing Group: Hoboken, NJ, USA, 2009; Volume 3. [CrossRef]

28. De Moraes, G.M.D.; de Abreu, L.R.; do Egito, A.S.; Salles, H.O.; da Silva, L.M.F.; Nero, L.A.; Todorov, S.D.; dos Santos, K.M.O. Functional properties of Lactobacillus mucosae strains isolated from Brazilian goat milk. Probiotics Antimicrob. Proteins 2016, 9, 235-245. [CrossRef] [PubMed]

29. Chopra, L.; Singh, G.; Choudhary, V.; Sahoo, D.K. Sonorensin: An antimicrobial peptide, belonginig to the heterocycloantharicin subfamily of bacteriocins, from a new marine isolate, Bacillus sonorensis MT93. Appl. Environ. Microbiol. 2014, 80, 2981-2990. [CrossRef] [PubMed]

30. Todorov, S.D.; Stojanovski, S.; Iliev, I.; Moncheva, P.; Nero, L.A.; Ivanova, I.V. Technology and safety assessment for lactic acid bacteria isolated from traditional Bulgarian fermented meat product "Lukanka". Braz. J. Microbiol. 2017, 48, 576-586. [CrossRef] [PubMed]

31. Dos Santos, K.M.O.; de Matos, C.R.; Salles, H.O.; Franco, B.D.G.M.; Arellano, K.; Holzapfel, W.H.; Todorov, S.D. Exploring beneficial/virulence properties of two dairy related strains of Streptococcus infantarius subsp. infantarius. Probiotics Antimicrob. Proteins 2020, 12, 1524-1541. [CrossRef]

32. Todorov, S.D.; Cavicchioli, V.Q.; Ananieva, M.; Bivolarski, V.P.; Vasileva, T.A.; Hinkov, A.V.; Todorov, D.G.; Shishkov, S.; Haertlé, T.; Iliev, I.N.; et al. Expression of coagulin A with low cytotoxic activity by Pediococcus pentosaceus ST65ACC isolated from raw milk cheese. J. Appl. Microbiol. 2019, 128, 458-472. [CrossRef]

33. Guinebretiere, M.-H.; Broussolle, V.; Nguyen-The, C. Enterotoxigenic profile of food-poisoning and food-borne Bacillus cereus strains. J. Clin. Microbiol. 2002, 40, 3053-3056. [CrossRef]

34. EUCAST. Available online: https:/ / www.eucast.org/ast_of_bacteria/ (accessed on 25 March 2020).

35. Valledor, S.J.D.; Bucheli, J.E.V.; Holzapfel, W.H.; Todorov, S.D. Exploring beneficial properties of the bacteriocinogenic Enterococcus faecium ST10Bz strain isolated from boza, a Bulgarian cereal-based beverage. Microorganisms 2020, 8, 1474. [CrossRef]

36. Ciffo, F. Determination of the spectrum of antibiotic resistance of the Bacillus subtilis strains of Enterogermina. Chemioterapia 1984, $3,45-52$.

37. McAuliffe, O.; Ryan, M.P.; Ross, R.P.; Hill, C.; Breeuwer, P.; Abee, T. Lacticin 3147, a broad-spectrum bacteriocin which selectively dissipates the membrane potential. Appl. Environ. Microbiol. 1998, 64, 439-445. [CrossRef] [PubMed]

38. Shelburne, C.E.; An, F.Y.; Dholpe, V.; Ramamoorthy, A.; Lopatin, D.E.; Lantz, M.S. The spectrum of antimicrobial activity of the bacteriocin subtilosin A. J. Antimicrob. Chemother. 2006, 59, 297-300. [CrossRef] [PubMed]

39. Masuda, Y.; Ono, H.; Kitagawa, H.; Ito, H.; Mu, F.; Sawa, N.; Zendo, T.; Sonomoto, K. Identification and characterization of leucocyclicin Q, a novel cyclic bacteriocin produced by Leuconostoc mesenteroides TK41401. Appl. Environ. Microbiol. 2011, 77, 8164-8170. [CrossRef] [PubMed]

40. Compaore, C.S.; Nielsen, D.S.; Sawadogo-Lingani, H.; Berner, T.S.; Nielsen, K.F.; Adimpong, D.B.; Diawara, B.; Ouedraogo, G.A.; Jakobsen, M.; Thorsen, L. Bacillus amyloliquefaciens subsp. plantarum strains as potential protective starter cultures for the production of Bikalga, an alkaline fermented food. J. Appl. Microbiol. 2013, 115, 133-146. [CrossRef]

41. Anihouvi, V.B.; Kpoclou, E.Y.; Hounhouigan, J.D. Use of starter cultures of Bacillus and staphylococcus in the controlled fermentation of Lanhouin, a traditional fish-based condiment from West Africa. Afr. J. Microbiol. Res. 2012, 6, 4767-4774. [CrossRef]

42. Chang, H.C. Healthy and safe Korean traditional fermented foods: Kimchi and chongkukjang. J. Ethn. Foods. 2018, 5, 161-166. [CrossRef]

43. Katz, E.; Demain, A.L. The peptide antibiotics of Bacillus: Chemistry, biogenesis, and possible functions. Biotechnol. Rev. 1977, 41, 449-474. [CrossRef]

44. Hosoi, T.; Kiuchi, K. Natto-A food made by fermenting cooked soybeanswith Bacillus subtilis (natto). In Fermented Functional Foods; Farnworth, E.R., Ed.; CRC Press: Boca Raton, FL, USA, 2003; pp. 227-251.

45. Cho, M.S.; Jin, Y.J.; Kang, B.K.; Park, Y.K.; Kim, C.K.; Park, D.S. Understanding the ontogeny and succession of Bacillus velezensis and B. subtilis subsp. subtilis by focusing on kimchi fermentation. Sci. Rep. 2018, 8, 7045. [CrossRef]

46. Jeon, H.H.; Jung, J.Y.; Chun, B.H.; Kim, M.D.; Baek, S.Y.; Moon, J.Y.; Yeo, S.H.; Jeon, C.O. Screening and characterization of potential Bacillus starter cultures for fermenting low-salt soybean paste (Doenjang). J. Microbiol. Biotechnol. 2016, 26, 666-674. [CrossRef]

47. Montel, M.C.; Masson, F.; Talon, R. Bacterial role in flavor development. Meat Sci. 1998, 49, S111-S123. [CrossRef]

48. El Mecherfi, K.-E.; Todorov, S.D.; de Albuquerque, M.C.; Denery-Papini, S.; Lupi, R.; Haertlé, T.; Franco, B.D.G.M.; Larré, C. Allergenicity of fermented foods: Emphasis on seeds protein based product. Foods 2020, 9, 792. [CrossRef] 
49. Park, H.; Lee, M.; Ji, Y.; Todorov, S.D.; Holzapfel, W.H. Safety evaluation and in vivostrain-specific functionality of Bacillus strains isolated from Korean traditional fermented foods. Probiotics Antimicrob. Proteins 2020, 13, 60-71. [CrossRef]

50. George, J. Elevated serum $\beta$-glucuronidase reflects hepatic lysosomal fragility following toxic liver injury in rats. Biochem. Cell Biol. 2008, 86, 235-243. [CrossRef] [PubMed]

51. Yang, E.J.; Chang, H.C. Characterization of bacteriocin-like substances produced by Bacillus subtilis MJP1. Korean J. Microbiol. Biotechnol. 2007, 35, 339-346.

52. Wu, S.; Jia, S.; Sun, D.; Chen, M.; Chen, X.; Zhong, J.; Huan, L. Purification and characterization of two novel antimicrobial peptides subpeptinJM4-A and subpeptinJM4-B Produced by Bacillus subtilis JM4. Curr. Microbiol. 2005, 51, 292-296. [CrossRef]

53. Salazar, F.; Ortiz, A.; Sansinenea, E. Characterisation of two novel bacteriocin-like substances produced by Bacillus amyloliquefaciens ELI149 with broad-spectrum antimicrobial activity. J. Glob. Antimicrob. Resist. 2017, 11, 177-182. [CrossRef]

54. Entian, K.-D.; de Vos, W.M. Genetics of subtilin and nisin biosyntheses. Antonie Van Leeuwenhoek 1996, 69, 109-117. [CrossRef]

55. Parisot, J.; Carey, S.; Breukink, E.; Chan, W.C.; Narbad, A.; Bonev, B. Molecular mechanism of target recognition by subtilin, a class I lanthionine antibiotic. Antimicrob. Agents Chemother. 2008, 52, 612-618. [CrossRef]

56. Zheng, G.; Yan, L.Z.; Vederas, J.C.; Zuber, P. Genes of the sbo-alb locus of Bacillus subtilis are required for production of the antilisterial bacteriocin subtilosin. J. Bacteriol. 1999, 181, 7346-7355. [CrossRef]

57. Nakano, M.M.; Zheng, G.; Zuber, P. Dual control of sbo-alb operon expression by the Spo0 and ResDE systems of signal transduction under anaerobic conditions in Bacillus subtilis. J. Bacteriol. 2000, 182, 3274-3277. [CrossRef] [PubMed]

58. Lee, N.-K.; Kim, W.-S.; Paik, H.-D. Bacillus strains as human probiotic: Characterization, safety, microbiome, and probiotic carrier. Food Sci. Biotechnol. 2019, 28, 1297-1305. [CrossRef]

59. Lee, H.; Kim, H.-Y. Lantibiotics, Class I Bacteriocins from the Genus Bacillus. J. Microbiol. Biotechnol. 2011, 21, 229-235. [CrossRef] [PubMed]

60. Le Marrec, C.; Hyronimus, B.; Bressollier, P.; Verneuil, B.; Urdaci, M.C. Biochemical and genetic characterization of coagulin, a new antilisterial bacteriocin in the pediocin family of bacteriocins, produced by Bacillus coagulans I(4). Appl. Environ. Microbiol. 2000, 66, 5213-5220. [CrossRef] [PubMed]

61. Cotter, P.D.; Ross, R.P.; Hill, C. Bacteriocins-A viable alternative to antibiotics? Nat. Rev. Microbiol. 2013, 11, 95-105. [CrossRef] [PubMed]

62. Joerger, R.D. Alternatives to antibiotics: Bacteriocins, antimicrobial peptides and bacteriophages. Poult. Sci. 2003, 82, 640-647. [CrossRef] [PubMed]

63. Vesterlund, S.; Vankerckhoven, V.; Saxelin, M.; Goossens, H.; Salminen, S.; Ouwehand, A.C. Safety assessment of Lactobacillus strains: Presence of putative risk factors in faecal, blood and probiotic isolates. Int. J. Food Microbiol. 2007, 116, 325-331. [CrossRef]

64. Barbosa, J.; Gibbs, P.A.; Teixeira, P. Virulence factors among enterococci isolated from traditional fermented meat products produced in the north of Portugal. Food Control 2010, 21, 651-656. [CrossRef]

65. Franz, C.M.A.P.; Muscholl-Silberhorn, A.B.; Yousif, N.M.K.; Vancanneyt, M.; Swings, J.; Holzapfel, W.H. Incidence of virulence factors and antibiotic resistance among enterococci isolated from food. Appl. Environ. Microbiol. 2001, 67, 4385-4389. [CrossRef]

66. Simon-Sarkadi, L.; Holzapfel, W.H.; Halász, A. Biogenic amine content and microbial contamination of leafy vegetables during storage at $5{ }^{\circ}$ C. J. Food Biochem. 1994, 17, 407-418. [CrossRef]

67. Özogul, Y.; Özogul, F. Chapter 1: Biogenic amines formation, toxicity, regulations in food. In Biogenic Amines in Food: Analysis, Occurrence and Toxicity; Royal Society of Chemistry: London, UK, 2019; pp. 1-17. [CrossRef]

68. Halász, A.; Barath, A.; Simon-Sarkadi, L.; Holzapfel, W.H. Biogenic amines and their production by microorganisms in food. Trends Food Sci. Technol. 1994, 5, 42-49. [CrossRef]

69. Halász, A.; Baráth, Ă.; Holzapfel, W.H. The influence of starter culture selection on sauerkraut fermentation. Z. Lebensm. Forsch. A 1999, 208, 434-438. [CrossRef]

70. Barbieri, F.; Montanari, C.; Gardini, F.; Tabanelli, G. Biogenic amine production by lactic acid bacteria: A Review. Foods 2019, 8, 17. [CrossRef] [PubMed]

71. Santos, M.H.S. Biogenic amines: Their importance in foods. Int. J. Food Microbiol. 1996, 29, 213-231. [CrossRef]

72. Brink, B.T.; Damink, C.; Joosten, H.M.L.J.; Veld, J.H.I. Occurrence and formation of biologically active amines in foods. Int. J. Food Microbiol. 1990, 11, 73-84. [CrossRef]

73. Atanasova, J.; Dalgalarrondo, M.; Iliev, I.; Moncheva, P.; Todorov, S.D.; Ivanova, I.V. Formation of free amino acids and bioactive peptides during the ripening of Bulgarian white brined cheeses. Probiotics Antimicrob. Proteins 2020, 13, $261-272$. [CrossRef] [PubMed]

74. Stribny, J.; Gamero, A.; Pérez-Torrado, R.; Querol, A. Saccharomyces kudriavzevii and Saccharomyces uvarum differ from Saccharomyces cerevisiae during the production of aroma-active higher alcohols and acetate esters using their amino acidic precursors. Int. J. Food Microbiol. 2015, 205, 41-46. [CrossRef]

75. Perea-Sanz, L.; Peris, D.; Belloch, C.; Flores, M. Debaryomyces hansenii metabolism of sulfur amino acids as precursors of volatile sulfur compounds of interest in meat products. J. Agric. Food Chem. 2019, 67, 9335-9343. [CrossRef]

76. Mah, J.-H.; Kim, Y.J.; No, H.-K.; Hwang, H.-J. Determination of biogenic amines in kimchi, Korean traditional fermented vegetable products. Food Sci. Biotechnol. 2004, 13, 826-829.

77. Tsai, Y.-H.; Kung, H.-F.; Lin, Q.-L.; Hwang, J.-H.; Cheng, S.-H.; Wei, C.-I.; Hwang, D.-F. Occurrence of histamine and histamineforming bacteria in kimchi products in Taiwan. Food Chem. 2005, 90, 635-641. [CrossRef] 
78. Jeong, D.-W.; Lee, J.-H. Antibiotic resistance, hemolysis and biogenic amine production assessments of Leuconostoc and Weissella isolates for kimchi starter development. LWT Food Sci. Technol. 2015, 64, 1078-1084. [CrossRef]

79. Jin, Y.H.; Lee, J.H.; Park, Y.K.; Lee, J.-H.; Mah, J.-H. The occurrence of biogenic amines and determination of biogenic amineproducing lactic acid bacteria in kkakdugi and chonggak kimchi. Foods 2019, 8, 73. [CrossRef] [PubMed]

80. Kim, M.-J.; Kim, K.-S. Tyramine production among lactic acid bacteria and other species isolated from kimchi. LWT Food Sci. Technol. 2014, 56, 406-413. [CrossRef]

81. Kang, H.-J.; Kim, B.-C.; Park, W. Isolation of tetracycline-resistnt lactic acid bacteria from kimchi. Korean J. Microbiol. 2004, 40, 1-6. (In Korean)

82. Suvorov, A. What is wrong with enterococcal probiotics? Probiotics Antimicrob. Proteins 2020, 12, 1-4. [CrossRef] [PubMed] 